\title{
EFFECTS OF SAND BLASTING WITH INDUSTRIAL ENZYME SILICON WASH ON DENIM APPAREL CHARACTERISTICS
}

\author{
Sumon Mazumder \\ Lecturer, Department of Textile Engineering, \\ Daffodil International University, Mirpur road, Dhaka-1207. \\ E-mail: sumon.te@daffodilvarsity.edu.bd
}

\begin{abstract}
Washing is one of the most important finishing treatments applied on apparels that have great usage to create special outlooks and improving the fashion. Technologically denim washing is the most important fashion element for clothing industry. Usually the term 'washing' is most significantly applied in case of sewn apparels so it is very essential to observe the effects that have been made by particular washing on the fabrics to hold the qualities of sewn apparels. The aim of this paper is to determine the effects of sand blasting with industrial enzyme silicon wash on denim apparel characteristics. For this investigation currently fashionable regular denim (100\% cotton with twill 3/1 weave construction) trouser was chosen. The selected denim trouser has been processed by enzyme and silicon washes after sand blasting. In order to evaluate the washing effects on denim trouser, changes of fabric handle, fabric specification (ends/inch, picks/inch, surface density, warp \& weft yarn linear density), fabric strength, seam strength \& fabric stiffness has been determined after sandblasting with enzyme silicon wash.
\end{abstract}

Keywords: Denim apparel, sand blasting, back staining, pumice stones, enzyme wash.

\section{Introduction}

Industrial washing is one of the most important applied finishing methods on fabric or apparel. Different washing methods can be applied incase of denim fabrics finishing. To achieve special outlooks as well as to change the fashion, responsible washing methods are stone wash, sand wash and bleach wash [1].Denim produced from the fabric with twill weave including warp yarns dyed with indigo color and undyed or white weft yarns [2].Sand blasting is a modern technique applied on specific portions of indigo dyed denim apparel with using special type of sands. These sands are sprayed on the selected portions of apparel at high pressure.
Sand removes color from those specific portions of the apparel and creates fashionable outlooks. After Sand blasting the apparel is washed with enzyme and silicon softener. Silicon softener is used to increase the softness of the apparel.

In recent years, many interests have been grown for using fully biodegradable enzymes which are environmentally friendly and nontoxic in the modern textile finishing process. A number of mechanical and chemical operations can be replaced by Enzymatic treatment, which have been applied to improve fabric quality and comfort ness $[1,3]$.In the textile industry enzymes are applied mainly to get a cleaner fabric surface with less fuzz, to reduce tendency to pill formation, to smooth the surface combining with traditional softeners [4].To improve fabric handle and other valuable properties, softeners are widely used in finishing operations [5].For buying a textile, nice and appealing handle is very often treated as the prior criterion. Fabric handle can be influenced by using softener which is analyzed in the research work [6].In case of stone wash there are difficulties of removing residual pumice from processed cloth items and difficult to reduce the damage to the equipment by the overload of tumbling stones. Pumice stones and particulate material can also clog machine drainage passages, drainage and sewer lines at the machine site. But sand blasting does not lead these types of problem.

Recently some papers have been published to analyze the change of textile's color after applying in different finishing methods as clients when choosing an item from shop always pay attention to its color [7-10]. Fabric specification (ends/inch, picks/inch, 
surface density, warp \& weft linear density), fabric tensile strength, fabric stiffness, seam strength etc must be treated as important characteristics as those determine wear durability and longevity. However the effects of sand blasting with enzyme silicon wash on the changes of above mentioned characteristics were not clearly evaluated before.

The aim of this paper is to determine the effects of enzyme silicon wash after sand blasting on denim apparel characteristics

\section{Materials and Methods \\ 2.1 Materials selection:}

The investigation has been carried out with currently popular and fashionable regular denim trouser. Basic characteristics of selected unwashed denim trouser are mentioned below-

Denim fabric composition: $100 \%$ cotton

Weave: twill 3/1 weave

Ends/inch: $50-51$

Picks/inch: 41-42

Surface density $\left(\mathrm{gm} / \mathrm{m}^{2}\right): 352-353$

Warp linear density $(\mathrm{Ne})$ : 6-7

Weft linear density (Ne): 11-12

The denim trouser has been processed by sand blasting, Desizing, enzyme washing and finally silicon softening method as mentioned below-

\subsection{Method of Sand blasting:}

Sand blasting is a mechanical treatment which has been done on denim trouser. For that purpose special sands were sprayed on the selected portions at a high pressure. Sand removed color from those portions of the trouser and created fashionable outlooks. After Sand blasting it was subjected to desizing process.

\subsection{Method of Desizing:}

Denim trouser has been subjected to Enzymatic desizing process for removal of size materials which were added in the sizing process to reduce ends breakage rate during weaving the fabric. Here desizing was carried out by using following suitable recipe with maintaining proper time and temperature -

Table 1 Recipe of enzymatic desizing

\begin{tabular}{|l|l|}
\hline Process parameters & Amount \\
\hline Soda ash & $500 \mathrm{gms}$ \\
\hline Caustic soda & $500 \mathrm{gms}$ \\
\hline Bio-D (Desizing Enzyme) & $200 \mathrm{gms}$ \\
\hline
\end{tabular}

\begin{tabular}{|l|l|}
\hline Temperature & $50-60^{\circ} \mathrm{C}$ \\
\hline Time & 20 minutes \\
\hline
\end{tabular}

After desizing the apparel was washed off for two times.

\subsection{Method of Enzymatic wash:}

By desizing size materials were completely removed from the denim trouser and after that it was washed by cellulase enzyme with industrial typical recipe as mentioned below-

Table 2 Recipe of enzymatic wash

\begin{tabular}{|l|l|}
\hline Process parameters & Amount \\
\hline Acid Enzyme & $400 \mathrm{gms}$ \\
\hline Acetic acid & $250 \mathrm{gms}$ \\
\hline Anti back staining agent & $200 \mathrm{gms}$ \\
\hline Temperature & $50-55^{\circ} \mathrm{C}$ \\
\hline Time & 20 minutes \\
\hline
\end{tabular}

During enzymatic treatment removed indigo dye can be re-deposited on the white or undyed weft yarn of denim fabric which is known as back staining process and it can diminish the outlooks of the trouser. So anti back staining agent was used here to resist back staining. After washing with enzyme the trouser was washed off for two times.

\subsection{Method of Softening}

After sand blasting and enzyme wash, to make the denim fabric soft and improve handle property, silicon softener was used as below-

Table 3 Recipe of fabric softening

\begin{tabular}{|l|l|}
\hline Process parameters & Amount \\
\hline Silicon softener (cationic) & $400 \mathrm{gms}$ \\
\hline Temperature & $40^{\circ} \mathrm{C}$ \\
\hline Time & 5 minutes \\
\hline
\end{tabular}

After softening the apparel was washed off for two times.

\subsection{Method of changes evaluation}

2.6.1 Change of Fabric Handle property: Fabric handle property was checked properly before and after sand blasting by feeling of touch.

2.6.2 Change of Fabric Specification:

By counting glass ends/inch and picks/inch were calculated from denim fabric of the trouser. GSM cutter was used to calculate the surface density (gram/square meter) of denim fabric by ISO 7211. To determine the warp 
and weft linear density (count) from denim trouser, beesleys direct reading balance was used by following ISO 7211/4:1984.

2.6.3 Change of fabric Strength:

Tensile strength of denim fabric was calculated by the help of fabric strength tester. EN ISO 13934 - 2; 1999Grab method was used for Tensile Strength measurement. 2.6.4 Change of fabric Stiffness:

Stiffness of denim fabric was measured by fabric stiffness tester. ASTM D1388 Standard test method was used for determination of fabric stiffness.

2.6.5 Change of Seam Strength:

Seam strength of trouser was measured by seam strength tester. EN ISO 13935 - 2; 1999 Grab method was used for that purpose

\section{Results and Discussion}

\subsection{Changes of Fabric Handle after washing}

01. Sand Blast Portions of denim trouser:

Before wash: Little bit Soft.

After wash: Softer.

02. Non - blast portions of denim trouser:

Before wash: Harsher.

After wash: Less Harsh.

After sand blasting surface of selected portions of denim trouser changed from harsh to little bit softer which finally changed into softer surface just after silicon wash.

\subsection{Changes of Fabric Specification after washing}

Table 4 Effects of sandblasting and enzymatic wash on fabric specifications

\begin{tabular}{|c|c|c|c|c|}
\hline & & & & \\
\hline 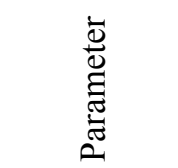 & $\begin{array}{ll}\overleftarrow{0} & \dot{0} \\
0 & 0\end{array}$ & 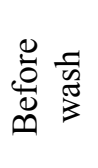 & 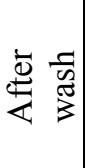 & $\begin{array}{l}\tilde{D} \\
\infty \\
\tilde{E} \\
\tilde{U}\end{array}$ \\
\hline & 1 & 51 & 52 & +1 \\
\hline & 2 & 50 & 51 & +1 \\
\hline Ends/inch & 3 & 51 & 52 & +1 \\
\hline & 4 & 51 & 53 & +2 \\
\hline & 5 & 51 & 52 & +1 \\
\hline & 1 & 41 & 44 & +3 \\
\hline & 2 & 42 & 45 & +3 \\
\hline Picks/inch & 3 & 41 & 43 & +2 \\
\hline & 4 & 41 & 43 & +2 \\
\hline & 5 & 42 & 43 & +1 \\
\hline Warp & 1 & 7 & 8 & +1 \\
\hline linear & 2 & 6 & 7 & +1 \\
\hline
\end{tabular}

\begin{tabular}{|c|c|c|c|c|}
\hline density & 3 & 7 & 8 & +1 \\
\cline { 2 - 5 } & 4 & 7 & 8 & +1 \\
\cline { 2 - 5 } & 5 & 7 & 9 & +2 \\
\hline \multirow{4}{*}{$\begin{array}{c}\text { Weft } \\
\text { linear } \\
\text { density } \\
(\mathrm{Ne})\end{array}$} & 1 & 11 & 11 & +0 \\
\cline { 2 - 5 } & 2 & 11 & 12 & +1 \\
\cline { 2 - 5 } & 3 & 12 & 12 & +0 \\
\cline { 2 - 5 } & 5 & 11 & 12 & +1 \\
\hline \multirow{4}{*}{$\begin{array}{c}\text { Surface } \\
\text { density } \\
(\text { gm/m }\end{array}$} & 1 & 353 & $\begin{array}{c}33 \\
2\end{array}$ & -21 \\
\cline { 2 - 5 } & 2 & 352 & $\begin{array}{c}33 \\
1\end{array}$ & -21 \\
\cline { 2 - 5 } & 4 & 352 & $\begin{array}{c}33 \\
0\end{array}$ & -22 \\
\cline { 2 - 5 } & 5 & 353 & $\begin{array}{c}33 \\
2\end{array}$ & -20 \\
\cline { 2 - 5 } & & & -19 \\
\hline
\end{tabular}

From the table for five (5) observations, it is clear that during sand blasting and enzyme wash since the fibres have been damaged by abrasion so the fabric supposed to loose its weight. The value of fabric surface density finally decreased though ends/inch picks/inch increased.

\subsection{Changes of Fabric strength and Seam strength after washing}

Table 5 Effects of sandblasting and enzymatic wash on fabric strength and seam strength

\begin{tabular}{|c|c|c|c|c|}
\hline 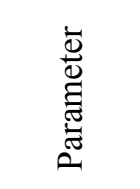 & 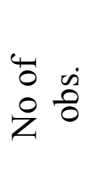 & 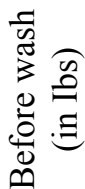 & 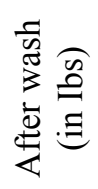 & 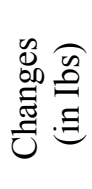 \\
\hline \multirow{5}{*}{$\begin{array}{l}\text { Tensile } \\
\text { Strength }\end{array}$} & 1 & 520 & 480 & -40 \\
\hline & 2 & 521 & 480 & -41 \\
\hline & 3 & 521 & 482 & -39 \\
\hline & 4 & 520 & 480 & -40 \\
\hline & 5 & 521 & 482 & -39 \\
\hline \multirow{5}{*}{$\begin{array}{l}\text { Seam } \\
\text { Strength }\end{array}$} & 1 & 81 & 62 & -19 \\
\hline & 2 & 80 & 62 & -18 \\
\hline & 3 & 80 & 62 & -18 \\
\hline & 4 & 82 & 63 & -19 \\
\hline & 5 & 81 & 60 & -21 \\
\hline
\end{tabular}

From the table for five (5) observations, it is clear that after sandblasting and enzyme wash the tensile strength of denim fabric as well as seam strength has been decreased from the values obtained before washing. 


\subsection{Changes of Fabric Stiffness after washing}

Table 6 Effects of sandblasting and enzymatic wash on fabric stiffness

\begin{tabular}{|c|c|c|c|c|c|}
\hline 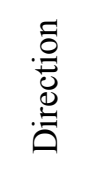 & $\frac{\theta}{\pi}$ & $\begin{array}{l}\dot{0} \\
0 \\
0 \\
40 \\
0 \\
0\end{array}$ & 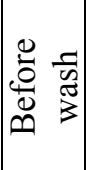 & $\begin{array}{l}\frac{\pi}{\pi} \\
\mathbb{E} \\
3 \\
\stackrel{\Xi}{\Xi}\end{array}$ & 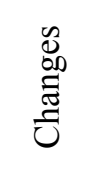 \\
\hline \multirow{4}{*}{ Warp } & \multirow{2}{*}{ Face } & 1 & 4.55 & 3.00 & -1.55 \\
\hline & & 2 & 4.40 & 2.95 & -1.45 \\
\hline & \multirow{2}{*}{ Back } & 1 & 4.65 & 2.65 & -2.40 \\
\hline & & 2 & 4.50 & 2.75 & -1.75 \\
\hline \multirow{4}{*}{ Weft } & \multirow{2}{*}{ Face } & 1 & 4.50 & 2.30 & -0.2 \\
\hline & & 2 & 2.50 & 2.20 & -0.3 \\
\hline & \multirow{2}{*}{ Back } & 1 & 2.50 & 2.45 & -0.5 \\
\hline & & 2 & 2.45 & 2.40 & -0.5 \\
\hline
\end{tabular}

From the table for two (2) observations along the warp and weft directions for both face and back side of denim fabric, it is clear that after enzymatic desizing process, size materials were removed from the fabric and for silicon softening, the stiffness of denim fabric has been decreased which indicating the increase of fabric softness.

\section{Conclusion}

The aim of this paper was to observe the effects of enzyme silicon wash with sandblasting on denim apparel characteristics. For that purpose a denim trouser was chosen as a apparel and after washing with sand blasting, changes on characteristics of denim trouser has been observed. After sandblasting and enzyme silicon wash the denim fabric changed from harsh to softer. Due to abrasion damage ends/inch and picks/inch of denim fabric has been decreased as a result surface density of fabric increased. Again tensile strength of fabric and seam strength of trouser has been decreased due to enzyme washing with sandblasting. Stiffness of denim fabric has been decreased after silicon wash which results the increase of denim fabric softness. To hold the qualities of sewn apparel it is very necessary to observe the effects of sandblasting with enzyme silicon wash on denim apparels. By this paper it will be possible to know how denim apparel characteristics can be changed by industrial enzyme silicon wash with sandblasting.

\section{References}

[1] Enzymes.http//www.cht-group.com/ (Downloaded: 05-03-2009, 08:25pm)

[2] Denim fabric: Properties and testing methods, standard and industrial researches of Iran Institute, 2194,1381

[3] Enzyme for Textiles. http//www.mapsenzymes.com/Enzymes_Textile.as p (Downloaded: 28-04-2009, 02:15pm)

[4] Buscle-Diller, G., Dong Yang, X. Enzymatic Bleaching of Cotton Fabric with Glucose Oxidase Textile Research Journal 71(5) 2001: pp.388-394.

[5] Milda jucienè, Vaida dobilaitè, Giedre Kazlauskaitè. Influence of Industrial Washing on Denim Properties Materials Science 12 (4) 2006: PP.355

[6] Webwr, R. New Aspects in Softening. ch R. Beitlin gmbh 1999: pp. 30.

[7] Blazevič, P., Strazdienè, E. The Application of Commercial Bleaches for Clothing Decoration Projektowanie, materialy, technologia skory, odziezy i obuwia Radom, Poland, 2004: pp. 143147.

[8] Dobilaite, V., Jucienè, M. Influence of Industrial Washing on Denim Garment Colours Change light industry-fibrous Materials: III International Scientific Conference Radom, Poland, 2005: pp. 309-314

[9] Militky, J., Bajzik, V. Influence of Washing/Ironing Cycles on Selected Properties of Cotton Type Weaves International Journal of clothing Science and Technology 9 (3) 1997: pp. 193-199.

[10] Alpay, H. R., Becerir, B., Akgun, M. Assessing Reflectance and Color Differences of Cotton Fabrics after Abrasion Textile Research Journal 75(4) 2005: pp.357-361.

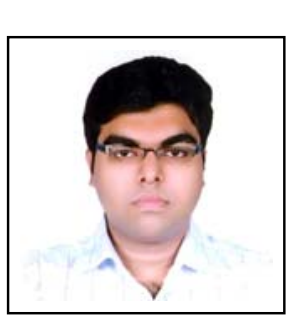

Sumon Mazumder received the B.Sc. in Textile Technology degree from College of Textile Engineering and Technology under the University of Dhaka in 2006. Since September 2008, he has been a Lecturer in the Department of Textile Engineering of Daffodil International University till present. He worked as a Lecturer in the Department of Textile Engineering of Primeasia University from February 2008 to September 2008. He also worked as Production Executive in a Textile Industry from January 2007 to February 2008. His research interest includes Textile Coloration, Textile Finishing and Garments Washing Technology. 